\title{
A VESZPRÉMVÖLGYI APÁCAKOLOSTOR RÉGÉSZETI KUTATÁSÁNAK LEGÚJABB EREDMÉNYEI
}

\author{
HÉCZEY-MARKó ÁgNES-KopPÁNY ANDRÁS*
}

The remnants of the medieval convent, whose remains had in part been excavated between 1998 and 2002, were investigated over a larger area during the salvage excavation preceding the conservation of the ruins in 2010. The investigations yielded new information on the architectural history and evolution of the complex. It also became clear that the date of the earliest architectural period can only be determined if the entire convent and its broader area can be archaeologically explored.

Keywords: Veszprém, medieval convent, architecture

A 2010. évi, a romterület helyreállitását megelöző ásatás során nagyobb felületen nyilt lehetôség a részben már 1998-2002 között feltárt maradványok további kutatására. Ennek eredményeként továbbgondolhatóvá vált az épületegyüttes épitéstörténete, kialakulása, kiépülése. Világossá vált, hogy csak további, a kolostor teljes területére és környezetére kiterjedó régészeti kutatás adhatna pontos választ a legkorábbi periódus kiépülésének korára.

Kulcsszavak: Veszprém, középkori apácakolostor, épitéstörténet

A veszprémvölgyi apácakolostor területén az 1930-as években folyt először ásatás és részleges helyreállítás, majd 1998 és 2002 között volt lehetőség nagyobb felületú régészeti és falkutatásra. Ezt a kutatómunkát fejeztük be 2010-ben, szervesen kapcsolódva a meginduló múemléki helyreállításhoz.

Az 1998-2002. évi kutatást Juan Cabello, majd Fülöp András vezette. Konzulensük Valter Ilona régész volt, munkatársként Koppány András és Bodó Balázs vett részt kezdettől fogva a feltáró munkában. ${ }^{1}$

A kézirat érkezett: 2015. március 27.

* Héczey-Markó Ágnes. Forster Gyula Nemzeti Örökségvédelmi és Vagyongazdálkodási Központ, 1113 Budapest, Daróci út 3.; agnes.marko@forsterkozpont.hu 2010-ben az ásatást Koppány András vezette. Munkatársként Kupovics Renáta és HéczeyMarkó Ágnes vettek részt a feltárás irányításában. Konzulensünk Fülöp András régész volt. A feltárás során előkerült falfestésmaradványok múvészettörténeti feldolgozását Veres Lujza, restaurátori vizsgálatukat Lovas Franciska végezte el.

A 2010. évi feltárás eredményeit bemutató tanulmányunk az új eredmények és következtetések összefoglalására törekszik, miközben az

Koppány András. Forster Gyula Nemzeti Örökségvédelmi és Vagyongazdálkodási Központ, 1113 Budapest, Daróci út 3.; andras.koppany@forsterkozpont.hu

1 Komoly segítséget jelentett számunkra Éder Katalin, Tassi Márta, Csapó Zita és Horváth Eszter szakmai munkája. Az ásatás eredményeiről: FÜLÖP-KOPPÁNY 2002; FÜLÖP-KOPPÁNY 2004. 
adott épületrész értelmezésénél röviden összegzi a korábbi kutatások vonatkozó adatait.

Tekintettel arra, hogy egy múemléki helyreállítást megelőző kutatás egyben a helyreállítás tervezésének is az alapja, és a kutatónak feladata, hogy bizonyos fokig bekapcsolódjon a helyreállítás tervezésének folyamatába, fontosnak tartjuk, hogy - ha röviden is - ismertetésre kerüljenek az építészeti tervezés legfontosabb szempontjai.

A veszprémvölgyi apácakolostor épületegyüttese a Veszprém városán átfolyó Séd patak völgyének nyugati - városszéli - szakaszán fekszik. A patakvölgyet itt délről magas sziklafal, északról pedig lankásabb, majd egyre meredekebb völgyoldal határolja.

Az egykori kolostor területének képét a 18. század óta alapvetóen meghatározza az a karcsú, architektúrájának részleteiben igen nívósan megépített barokk kápolna, amelyet a középkori romokon emelt az akkori birtokos jezsuita rend.

Az épületegyüttes legutolsó periódusában egy nagyméretú, trapéz alakú udvar köré szervezódött, egytraktusos épületszárnyakból állt, amelyek közül a keleti szárny dél felé kiugrott a kolostor déli homlokzati síkjához képest. Az udvart csak keleti és északi oldalának egy részén övezte folyosó. A templom a kolostorépület északkeleti szakaszához csatlakozott, kelet felé. A végül is két templomból - egy dél felé elhelyezkedő, kisméretú Árpád-kori és egy annak északi falához hozzáépített, nagyméretú késő gótikus templomból - álló épületrészt észak felól temető- és épületmaradványok, dél felól támfallal támasztott teraszok határolták a Séd felé, amelyek közül a legfelső teraszrész a kolostor temetőjeként is szolgált.

A több éven át tartó régészeti feltárás és falkutatás során a fentebb leírt, 1543-ban a török közeledtének hírére az apácák által elhagyott kolostor kiépülésének építéstörténetét vizsgáltuk. Azt a folyamatot, amelynek során - a Szent István-kori alapítástól kezdve - az apácakolostor jövedelmeiből vagy világi támogatóik adományaiból tovább építették vagy éppen átépítették, felújították az épületeket.

\section{Történeti adatok}

Az apácakolostor alapítólevelének szövege Kálmán király 1109-es átírásában maradt fenn. ${ }^{2}$

2 Az oklevél két példányban maradt fenn, amelyek közül ma az ún. múzeumi példányt tekintjük az eredeti, 1109-es ok-
Az oklevél különlegessége, hogy a másoló a hártya felső részére átírta az eredeti alapítólevél görög nyelvú szövegét, amely az István király által adományozott birtokokat sorolja föl, majd alá az eredeti oklevél latin renovációját. ${ }^{3} \mathrm{Az}$ oklevéllel kapcsolatban máig tartó vita bontakozott ki arról, vajon minek köszönhetők az eredeti görög szöveg diplomatikai hiányosságai és a birtokok felsorolásában tapasztalható következetlenség. Ma a kutatás általában azon az állásponton van, hogy a görög átírás az István-kori oklevél szó szerint átírt másolata, hiányai és vulgáris görögsége pedig a korai kancelláriai gyakorlat kezdetlegességével magyarázhatók. ${ }^{4}$

A másik sokat tárgyalt kérdés, hogy miért görög nyelvú az alapítólevél, amikor a korabeli magyarországi monostorok alapítólevelei latinul íródtak. A latin renováció gyakran idézett mondata szerint az eredeti alapítólevél „az alapító nyelve szerint íratott görögül" (iuxta linguam auctoris monasterii grece scriptum). Mivel a fenti megjegyzés nem vonatkozhat Istvánra, az auctor szó mögött a „létesíto"” 5 vagy még inkább a „kezdeményező" 6 jelentést kell keresnünk. Ezért vetette fel Moravcsik Gyula, hogy a király valamelyik közeli családtagjának, vélhetően Imre herceg név szerint nem ismert, bizánci származású jegyesének szánhatta a monostoralapítást. ${ }^{7}$

A veszprémvölgyi alapítólevél további kérdése a monostor alapításának dátuma. A görög szöveg kelte ugyanis nem szerepel az átíró oklevélben, így csupán a latin renováció azon megjegyzésére hagyatkozhatunk, amely az eredeti oklevelet egyértelmúen István királyhoz köti (privilegium sancti

levélnek, míg az ún. országos levéltári példány keletkezése 1290-1295 közé tehető. A témával részletesen foglalkozik: HómAN 1911, 123-134, 167-174. Az ún. országos levéltári példány kiadása: FEJÉRPATAKY 1892, 195-282; az ún. múzeumi példány hasonmás kiadása: GYOMLAY 1901, 391-434; vö. még: SZENTPÉTERY 1923, 1, 15-16; a görög oklevélről: MORAVCSIK 1984, 79-81. Mindkét oklevél legújabb kiadása az addigi irodalommal: GYÖRFFY 1992, 81-85, 365-380.

3 A monostor kiemelkedő jelentőségét mutatja, hogy István király kivette az illetékes megyés püspök irányítása alól, és közvetlenül az esztergomi érsek alá rendelte. Az apácakolostor nem csak az egyházi tized neki járó részét szedte be birtokain, hanem részben annak a 13. századtól kötelezően helyben, a papnál maradó hányadát is (RÁcz 2000, 186-188). Az eredeti oklevél feltételezhető pecsétjéről: SZENTPÉTERY 1938, 197.

4 DARKó 1917, 336-351; HÓMAN 1917, 225-242.

5 Ezt a fordítást közli: GYÖRFFY 1977, 322.

6 Érszegi Géza szerint esetleg magára a bizánci uralkodóra is vonatkozhat az auctor szó: ÉRSZEGI 1988, 3-14; vö. még: SZENTPÉTERY 1930, 3, 5.

7 Az elgondolás alapját az Árpád-házi Szent Margit-legendák egyik értesülése képezi: HoRVÁt 1834; MoRAVCSIK 1938, 408416. 
Stephani). ${ }^{8}$ Hogy a király uralma alatt melyik időszak jöhet számításba, mindenesetre kérdéses. ${ }^{9}$ Moravcsik Gyula és Györffy György a monostor létrehozását legkorábban 1015-1018 körül, a magyar-bizánci szövetség létrejöttének idején tartja elképzelhetőnek, elfogadva Imre herceg görög jegyesének az alapításban játszott szerepét. ${ }^{10} \mathrm{Itt}$ jegyezzük meg, hogy a monostorra vonatkozó későbbi oklevelek is hallgatnak a monostor rendi hovatartozásáról, így annak - a szakirodalomban gyakran emlegetett - görög rítusára vonatkozóan csak az átíró oklevél már említett, homályos utalására hagyatkozhatunk.

Az apácakolostor későbbi történetének lényeges mozzanata, hogy a monostor 1240-ben a ciszterciek fennhatósága alá került, miután IV. Béla király annak felvételét kérte a rendbe. ${ }^{11} \mathrm{Az}$ írott források arról tanúskodnak, hogy a 13. század második felében az apácák nagyobb építkezésbe fogtak, sőt szó esik a monostor templomának újjáépítéséról is. ${ }^{12} \mathrm{Az}$ apácakolostor újabb nagy átépítésére a 14. század végén került sor. A munkálatok egyik részéról egyedülálló módon fennmaradt egy 1387. május 5-én kelt szerződés, amelyben az apácák megállapodtak egy építómesterrel a meglévő épületek felújításáról és egy új épületszárny felhúzásáról. Ez utóbbinak a méreteit is pontosan meghatározták. ${ }^{13}$

A veszprémvölgyi monostor történetét a közelgő török veszély zárta le. Az apácák az ellenség közeledtére felszámolták a kolostort. Levéltáruk - benne az alapítólevél másolatával 1543-ban Körmendre, onnan 1627-ben a győri jezsuitákhoz került. Ök birtokolták a kolostor területét is. Csak 1744-ben láttak hozzá egy új templom építéséhez, ${ }^{14}$ amely azonban sosem fejeződött be. Amikorra ugyanis teljesen elkészült volna a templom, 1773-ban Mária Terézia a Habsburg Birodalom területén feloszlatta a jezsuita rendet. $^{15}$

8 Korábban többen próbálták a monostor alapítását István király apjához, Géza fejedelemhez kötni: BALOG 1946, 21-30; LÁsZló 1963, 382-397; KOMJÁTHY 1971, 33-49.

9 István király uralkodásának elejére keltezte az oklevelet: HÓMAN 1917, 225-242; SZENTPÉTERY 1938, 135-202; István uralmának második felére, végére valószínúsíti: ÉRSZEGI 2000, 159-175.

10 MorAVCSIK 1938, 408-416; GYÖRFFY 1977, 323, 374.

11 HeRvay 1984, 193.

12 CD VII/1. 362, IX/4. 497; SZENTPÉTERY 1923, 507

13 ZsO I. 53. sz. regeszta; magyar fordításai: GuTHEIL 1977, 161-162; MMúv 177. Véleményünk szerint az épület méreteit leíró mértékegység, az ulna - szemben az eddigi fordításokkal - rőföt (62,52 cm) jelent (vö. BoGDÁN 1978, 97, 105-106). Ez alapján a ház hosszúsága 21,26 m, szélessége 4,4 m körül lehetett.

14 MRT 2, 51/9a.

15 GUTHEIL 1977, 163-164; MRT 2, 51/9a.

\section{A 2010. évi kutatás}

Mint minden múemlék épület helyreállítást megelőző régészeti és/vagy falkutatásánál, a veszprémvölgyi apácakolostor feltárásánál is azt a módszertani kutatási elvet alkalmaztuk, amely szerint a feltárt épített maradványokat mindig, minden részletükben megőrizni törekszünk - hiszen helyreállításra kerülnek. Még abban az esetben is a megőrzés a cél, ha az adott objektumok - elsősorban épített falazatok, járószintek - ráfednek korábbi, az épület periodizációinak megismerése szempontjából fontosnak ítélhető, kronológiailag korábbi részletekre.

2010-ben négy területen folytattuk a kutatást (1. kép).

1. Befejeztük a középkori templomok feltárását.

2. Nagy felületen rábontottunk az Árpád-kori templomtól nyugat felé elhelyezkedő területre és az egykor itt állt épületrészek maradványaira.

3. Befejeztük az Árpád-kori templomtól délre fekvő, kis területú temető feltárását. Itt került elő 2001-ben egy rozmáragyarból készült, a 11. század végére, a 12. század elejére datálható, díszes Tau-botvég. ${ }^{16}$

4. Új feltárás keretében kutattuk a kolostorudvart övező északi és nyugati épületszárnyakat.

\section{A középkori templom feltárása}

1998 és 2002 között feltártunk egy kisméretú, egyenes szentélyzáródású templomot, amelynek falait közvetlenül a sárga altalaj felett fekvő, 1011. századi és néhány egyértelmúen 13 . századi kerámiát tartalmazó, barna agyagos-faszenes rétegbe vágták bele. A 13. századi kerámiák - a réteg finombontása alapján - egyértelmúen ebben a rétegben, annak felszínén feküdtek. ${ }^{17}$ A barna agyagos-faszenes rétegre közvetlenül ráfednek a templom öntött mészhabarcs padlójának foltszerúen megmaradt részletei, egy ezekhez szervesen illeszkedő lépcső faragott kőeleme, amely az emeltebb szentélytérbe vezetett, és egy a szentély keleti faláig futó, meszes omladék, amely az emeltebb szentélypadló alatti planírozás. Ehhez a feltárások során megismert legkorábbi templomhoz a 13. század végén, a 14. század elején kriptával rendelkező, díszesen kifestett oldalkápolnát építettek, amelyet a templom északi falán nyitott átjárón/ajtón lehetett megközelíteni. Az oldalkápolna építésekor a két épület állékonyságának megerősítésére a templom északi falának hajó felőli síkja elé köpenyezést építet-

16 FÜLÖP-KOPPÁNY 2004, 121-122.

17 FÜLÖP-KopPÁNY 2002, 16-17, 50-53. jegyzet. 


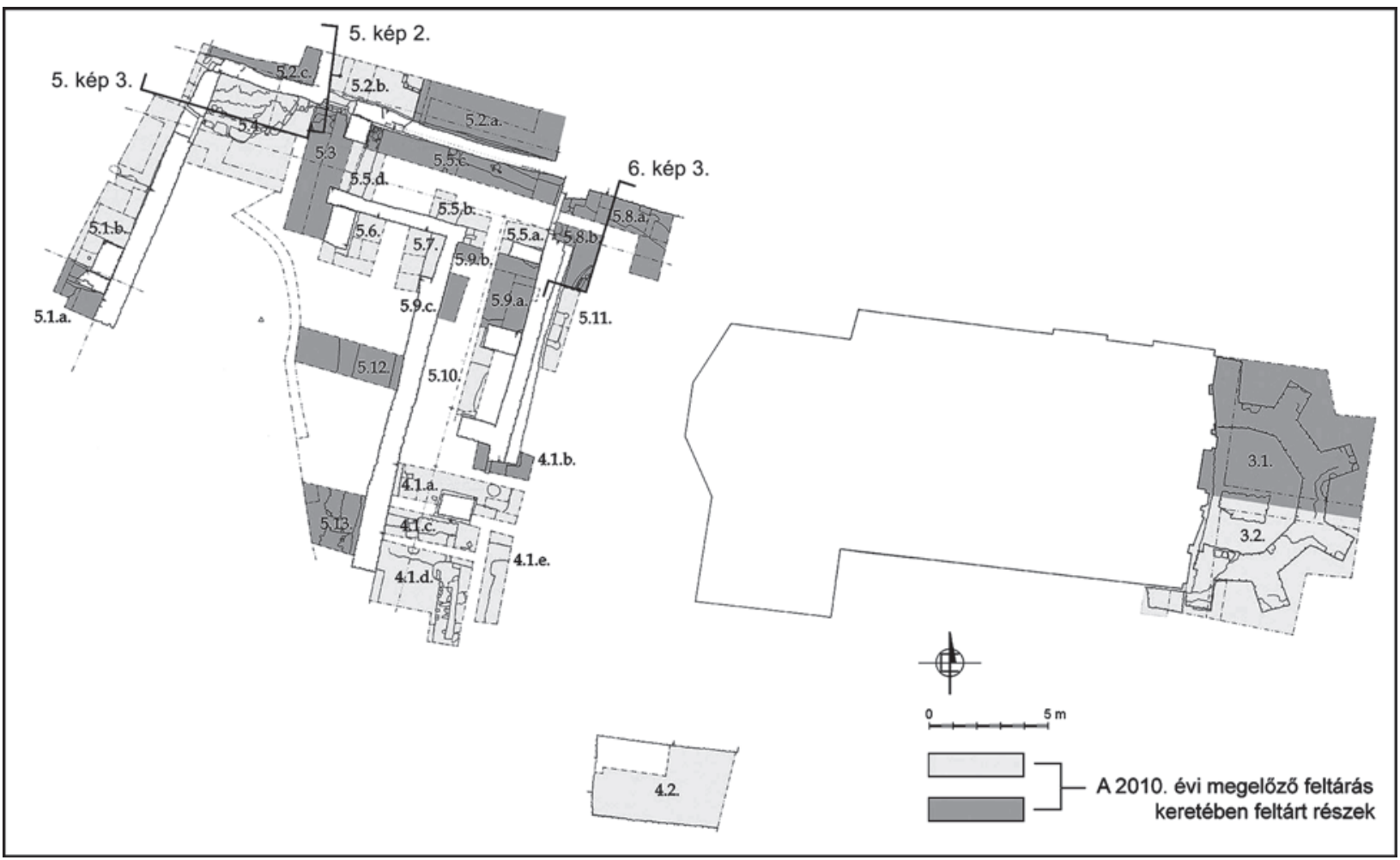

1. kép. Veszprémvölgy. A 2010. évi régészeti feltárás összesítő, árokszámozást tartalmazó alaprajza, az 5. kép 2-3 és a 6. kép 3. rajznézetei vonalainak jelölésével (Rajz: Héczey-Markó Ágnes)

Fig. 1. Veszprémvölgy. Combined plan of the archaeological excavation in 2010 with the excavation trenches (drawing by Ágnes Héczey-Markó)

tek, és az így megvastagított északi falban alakították ki az említett átjárót. E két fal falkiszedési árkának lenyomata világosan kirajzolódott a sárga agyagos altalajban. Az átépítésnek jelentős bontási munkával kellett járnia, ami a templombelső járószintjeit is érintette. Mindezek alapján a templom építési idejének meghatározásakor alapvetően két hipotézist kell felvetnünk. Amennyiben a templom a 13. század második felében épült, a régészeti feltárás során nem találtuk meg a 11-12. századi templomot, az máshol helyezkedett el. A másik lehetőség, hogy az oldalkápolna felépítésekor jelentősen átépített északi hajófal építési munkái során kerültek a kerámiák a barna agyagos-faszenes réteg felszínére; ebben az esetben a templomot legkorábban a 11. században építették. Nem zárható ki ugyanakkor az sem, hogy az oldalkápolna felépítése előtt folyt építkezés a templombelsőben a 13. század során.

Magát az oldalkápolnát el is bontották - a bontási törmelékből előkerült Nagy Lajos-obulus érme alapján az 1370 -es években. ${ }^{18}$ A bontásra minden bizonnyal már a késő gótikus templom

18 FÜLÖP-KopPÁnY 2002, 22, 59. jegyzet. felépítésének előzményeként került sor. A gótikus templom így részben az egykori oldalkápolna elplanírozott bontási törmelékére, részben az ott fekvő temetô területére épült.

A már említett 18. századi barokk jezsuita kápolna gyakorlatilag e késő középkori templom hajójára épült fel, úgy, hogy északi falát közvetlenül a középkori falazatra építették, déli falát pedig a középkori déli fal belső síkja elé. 1998-2002ben teljesen feltártuk ennek a templomnak a hajóját, és néhány árokkal tájékozódtunk a gótikus szentély kialakításáról is. A szentély teljes feltárására 2010-ben került sor (2. kép).

A szentélyt a jezsuita templom bejárata előtti területen, az ott futó modern út alatt tártuk fel, két nagyméretǔ szelvény nyitásával. A jezsuita templom előtt és a két szelvény között 1 méter széles tanúfalat hagytunk.

A nyolcszög öt oldalával záródó, sarkain öszszesen hat támpillérrel erősített szentély falait a barokk templom építésekor, az 1740-1770-es években - a déli szentélyfal rövidebb, nyugati szakaszának kivételével - megközelítőleg egységes szintre, az alapfalakig bontották vissza. A falakat a sárga altalajba alapozták. A déli szentélyrészt magában foglaló szelvény délnyugati 


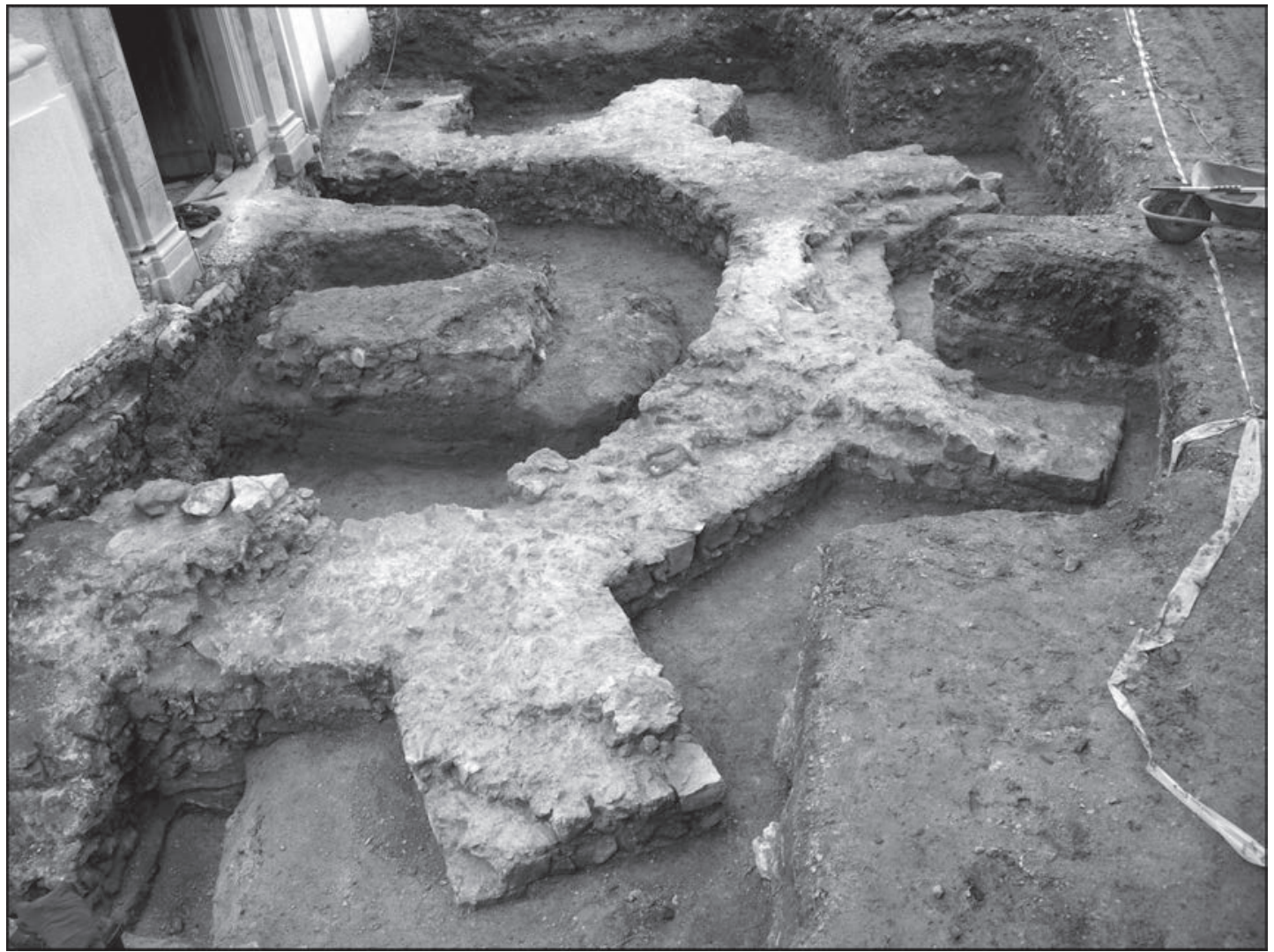

2. kép. Veszprémvölgy. A késő gótikus templom szentélye a teljes feltárás után, a barokk jezsuita templom kapujának előterében (Kupovics Renáta felvétele)

Fig. 2. Veszprémvölgy. The sanctuary of the late Gothic church after its complete excavation, in the foreground of the Baroque Jesuit church entrance (photo by Renáta Kupovics)

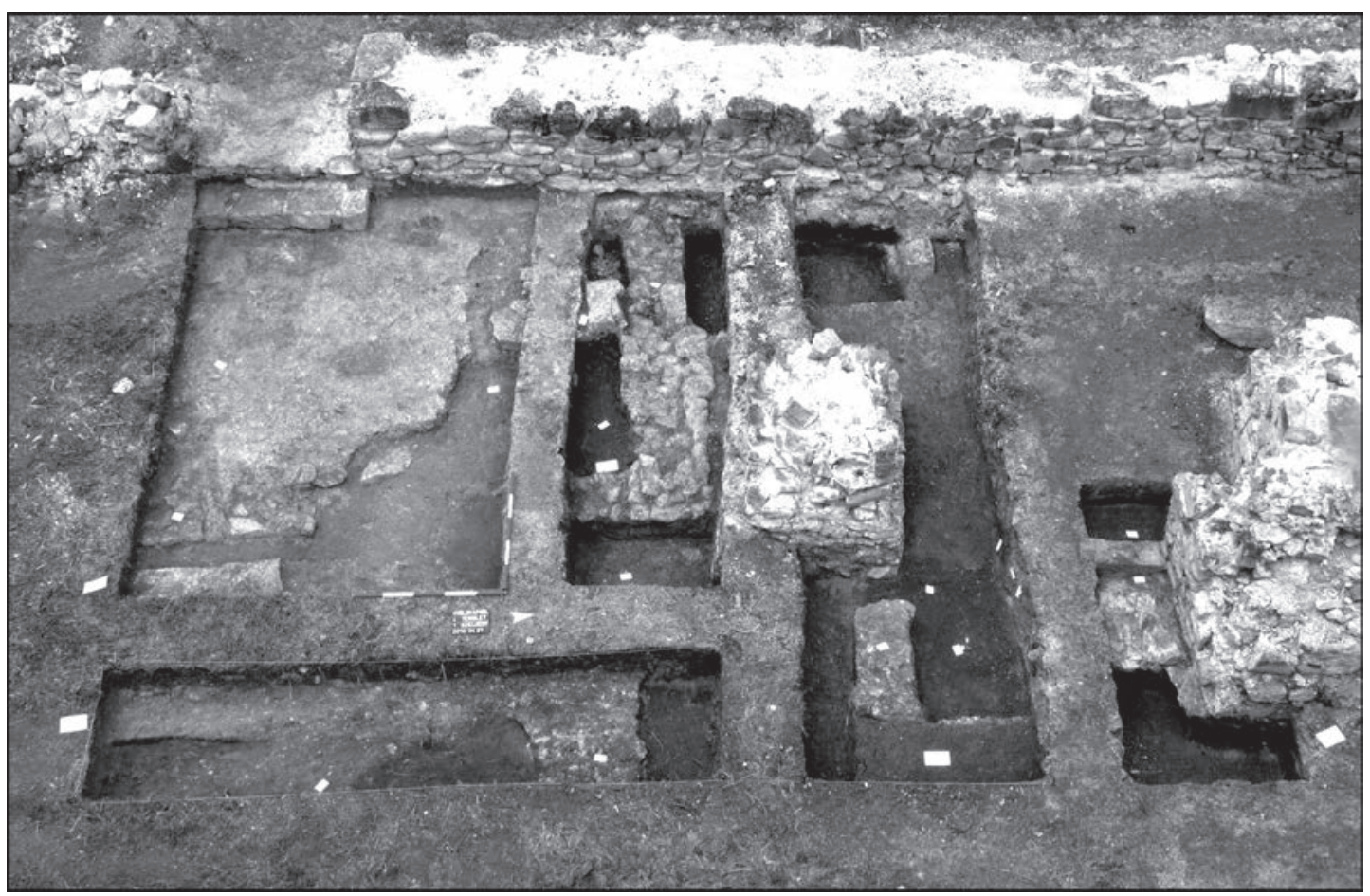

3. kép. Veszprémvölgy. A késő középkori udvari folyosó által vágott 14. század végi épület maradványa (Koppány András felvétele)

Fig. 3. Veszprémvölgy. Remains of the late 14th-century building cut by the late medieval courtyard corridor (photo by András Koppány) 


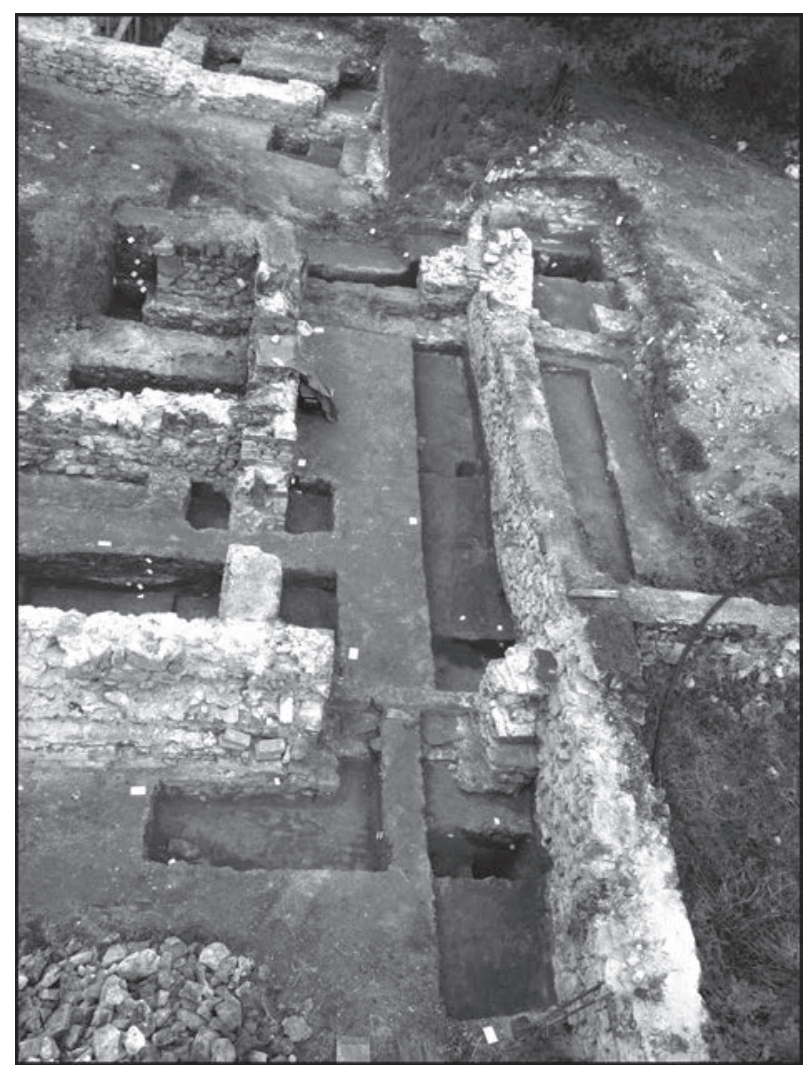

4. kép. Veszprémvölgy. Összkép a nyugati és északi épületrészeknél végzett kutatásról (Koppány András felvétele)

Fig. 4. Veszprémvölgy. View of the investigation of the western and northern buildings (photo by András Koppány)

sarkában egy keskenyebb szakaszon megkerestük a délnyugati pillér és a déli szentélyfal alapozási padkáját, illetve alapozásának alját. Mindebből megállapítható volt, hogy a pillér sekélyebb alapozással rendelkezik, mint a szentélyfal, alapozási padkájuk ugyanakkor közös, és az alapfalak is kötésben állnak egymással. A déli szentélyfal magasabb szintig visszabontott szakasza egy markáns függóleges elválással különül el a fal folytatásától. Az északi szentélyfalon megközelítóleg az említett repedéssel egy vonalban - hasonló, bár kevésbé szembetúnó elválást fedezhetünk fel. Mindebből a szóban forgó épületrész nyugati részének megsüllyedésére vagy egy építkezésen belüli fáziskülönbségre következtethetünk. A jelenség mindenesetre jelentős statikai problémákat okozhatott a maga korában, a még álló épület vonatkozásában.

A szentélybelső felóli alapozási padka csupán a déli szentélyfal magasabban fennmaradt, rövidebb nyugati szakaszán őrződött meg. A két (külsó és belsó) alapozási padka elhelyezkedése alapján következtethetünk a korabeli szintviszonyokra. Az adatok alapján az egykor feltehetően magasított szentélyen belül és az épületen kívül jelentős szintkülönbséggel kell számolnunk.

Az egykori szentélybelsőben és a szentély falain kívül is vastag, sötétbarna sávokkal, rétegekkel tagolt, sárga agyagos feltöltés húzódott, amelyre a vörös habarcsba rakott, tört kövekból álló, sekély alapozású, kissé hevenyészett oltáralapot emelték. A kb. $40 \mathrm{~cm}$ magas, $3,15 \mathrm{~cm}$ széles oltáralap felületén is a vörös falazóhabarcsot terítették szét.

A szentély falain kívül az említett feltöltési réteg kb. $30 \mathrm{~cm}$-rel nyúlik az alapozási padka fölé. Az egykori járószinteket e feltöltési réteg felső határa jelöli ki. Az épületen kívül a pusztulási és bontási rétegek mellett modern feltöltési rétegeket is találtunk. A bontási rétegek nagyobb menynyiségben tetőcserép-, kisebb részben kannelúrázott téglatöredékeket tartalmaztak.

A szentély kutatása során összesen három kőfaragvány került elő. A fal, illetve az oltáralap omladékából két vörös kóből faragott körtetagtöredéket ismerünk, amelyek egykor feltehetően a szentély boltozatához tartoztak. A kisebb töredéken vörös festésnyomokat, a nagyobb, épebb darabon fehér meszelésnyomokat fedezhetünk fel. A faragott kövek közül még egy sokszögletesre munkált lábazati vagy párkányelem érdemel említést.

\section{A nyugati terület kutatása}

2010-ben az Árpád-kori templom nyugati homlokzati falától tovább nyugat felé szinte a teljes területet feltártuk. Ezen a felületen már 2000-ben is kutattunk, és az igen sekély rétegsorok alatt, közvetlenül az altalaj felett feltártunk egy négyzet alakú, vaskos falú építményt, amely majdnem olyan széles, mint maga a korai templom hajója. Az építményt a templom tornyaként azonosítottuk. Teljes feltárása 2010-ben igazolta korábbi feltevésünket. Közvetlenül a toronyhoz északról - a keleti kolostorszárnyat észak felé lezáró-téglaboltozatos, ablaktalan tárolóhelyiség csatlakozik, amely a legépebben megmaradt egykori épületrész az egész kolostorból. Érdekessége, hogy keletnek tartó tompaszöget zár be a torony és a hajó hossztengelyével. A toronyhoz dél felé kétosztatú térsor csatlakozik, amelynek utolsó helyisége dél felé kissé túlfut az egész kolostor déli külsó homlokzati falán. A toronytól nyugatra, részben a toronnyal, részben a tóle dél felé nyúló, kétosztatú épülettel párhuzamosan már 2000-ben egy épület romjai kerültek elő. Ezt az épületet egykor visszabontották, hiszen a keleti kolostorszárny folyosójának fala vágja területét. 


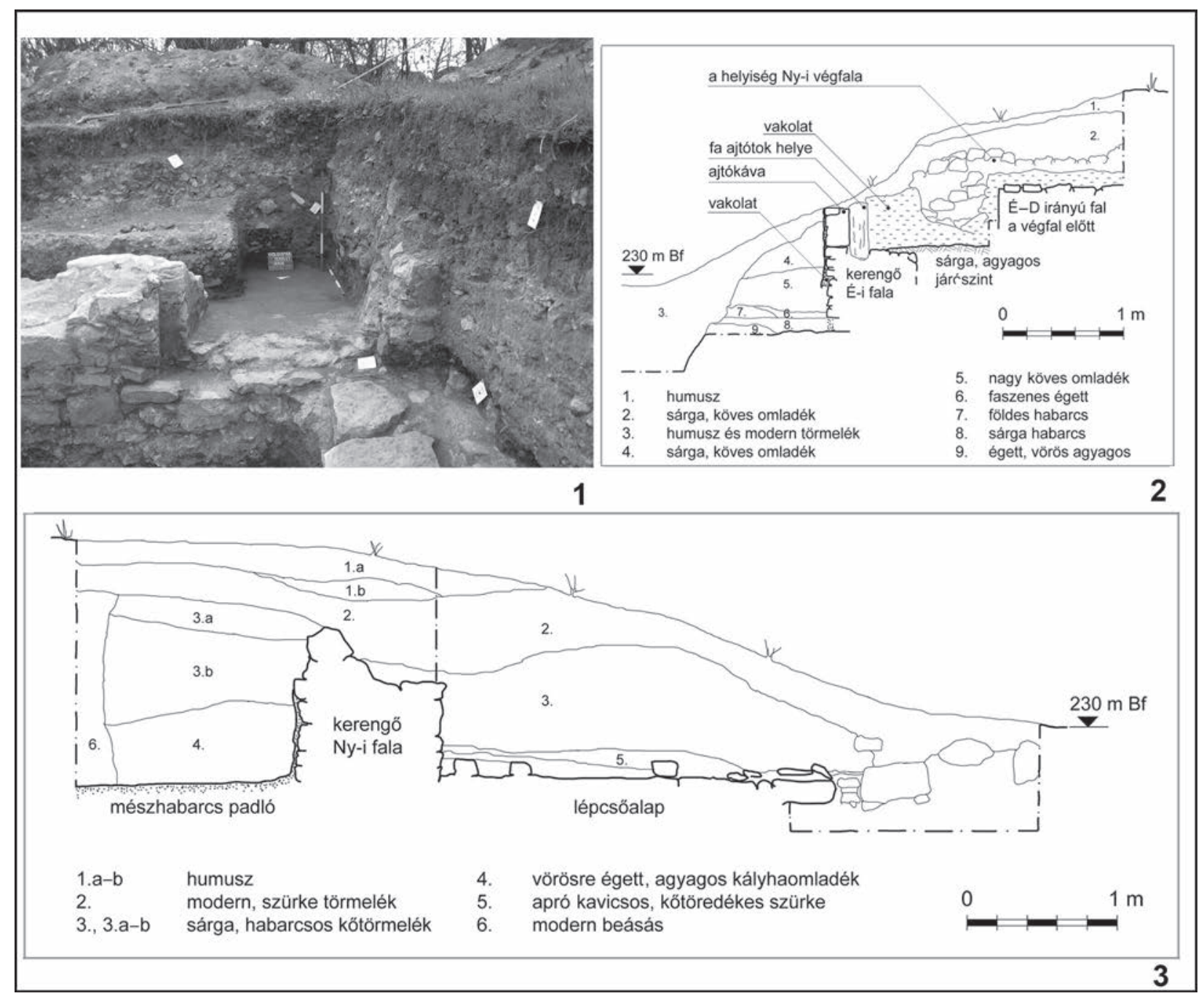

5. kép. Veszprémvölgy. 1: A nyugati szárny helyiségébe nyíló udvari ajtó maradványa (Koppány András felvétele); 2: Az 5.2.b és 5.3. árkok nyugati metszetfala. Az északi, emelt padlójú helyiségbe vezető ajtó maradványa (Rajz: Héczey-Markó Ágnes); 3: Az 5.1.b és 5.4. árkok északi metszetfala. A nyugati szárny belső terének maradványa és a külső járószint az udvar északnyugati sarkában lévő lépcsőalap előterében (Rajz: Héczey-Markó Ágnes)

Fig. 5. Veszprémvölgy. 1: Remains of the door opening into a room of the western wing (photo by András Koppány); 2: Western section of Trenches 5.2.b and 5.3. Remains of the door opening into the northern room with raised floor (drawing by Ágnes Héczey-Markó); 3: Northern section of Trenches 5.1.b and 5.4. Remains of the interior of the western wing and the external occupation level in front of the steps in the courtyard's north-western corner (drawing by Ágnes Héczey-Markó)

Az igen elroncsolt maradványú épületnek csupán két helyisége maradt meg. A két helyiség osztófalában egy fútőszerkezet alapozása került elő. Az épület északi, egykori homlokzati falának vonala egybeesik a torony északi falának vonalával. Már a 2002-ben lezárult kutatás eredményeinek elemzésekor úgy véltük, hogy ez az épület azonos lehet egy a kolostorról szóló 14. századi írott forrásban szereplő épülettel, amelyet egy bizonyos Konch mesternek kellett felépítenie az apácákkal történt írásos megállapodás alapján. ${ }^{19}$
A szerződésből kiderül, hogy az új épület földszintje kéthelyiséges volt: az egyik betegszobának készült (pro infirmorio), a másik melegedőhelyiségnek (pro estuario). Az emeleten kialakított termet hálóteremként (pro dormitorio) kívánták használni az apácák. ${ }^{20}$

A 2010-es kutatás alapján, amelynek során sikerült feltárnunk az épület északi végét, megerósíthetjük azt a hipotézist, hogy az épület azonosítható a Konch mester által építettel (3. kép). 

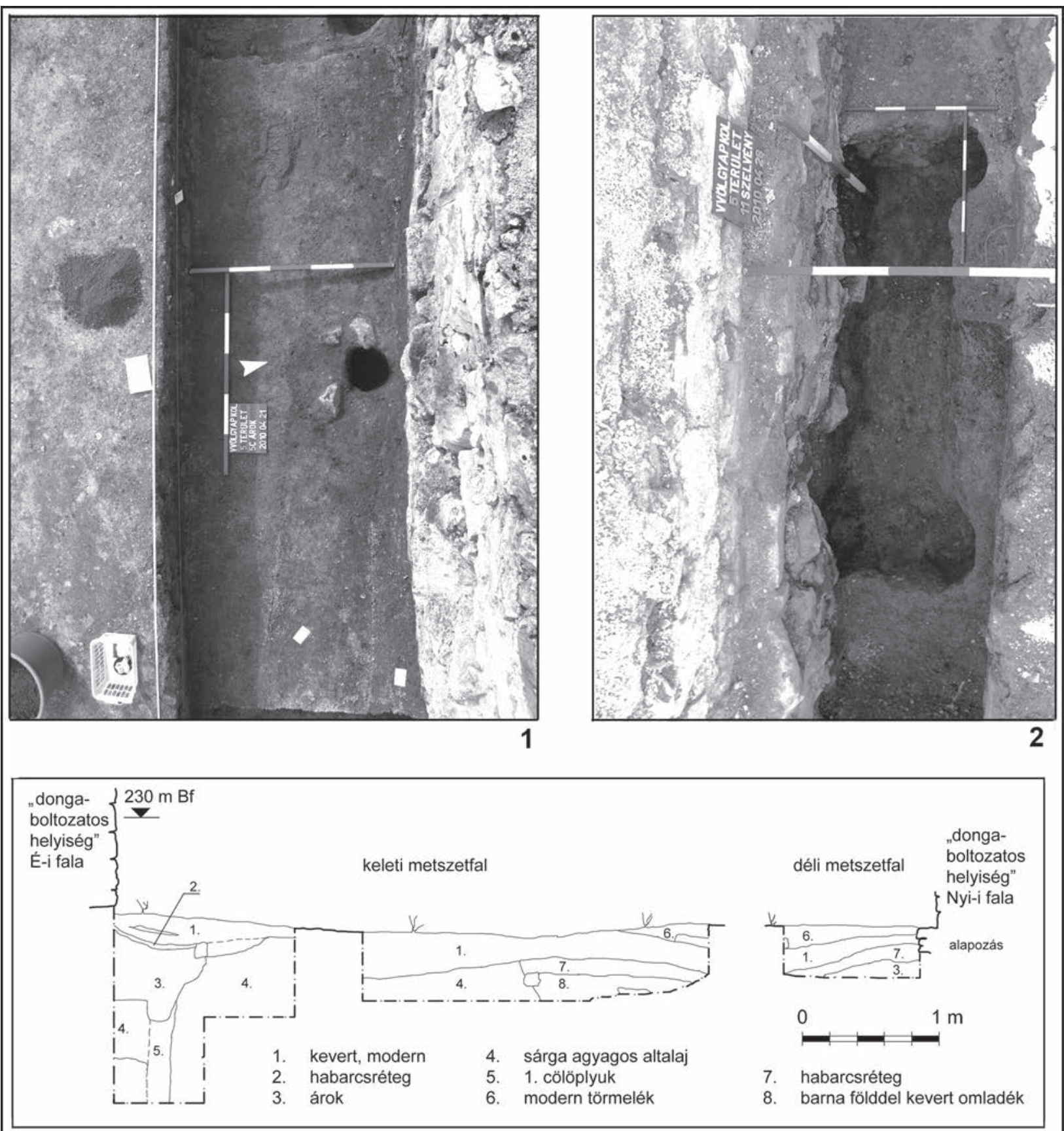

6. kép. Veszprémvölgy. 1: Az északi udvari épületszárny előtti folyosón feltárt árok, még 13. századi betöltésének kibontása előtt, utólag beleásott cölöplyukkal; 2: Faszerkezetes objektum a keleti kolostorszárny északi végén álló, dongaboltozatos helyiség belső terében, az udvari fal síkja előtt (Koppány András felvételei); 3: Az 5.9. és 5.5. árkok nyugati metszetfala, a rajz bal oldalán a 13. századi betöltést tartalmazó árokkal (Rajz: Héczey-Markó Ágnes)

Fig. 6. Veszprémvölgy. 1: Ditch running along the corridor in front of the northern wing, before the excavation of its 13th-century fill, with a later post-hole dug into it; 2: Post-framed structure in the interior of the barrel-vaulted room at the northern end of the eastern wing (photo by András Koppány); 3: Western section of Trenches 5.9 and 5.5, with the ditch containing the 13th-century fill on the left side (drawing by Ágnes Héczey-Markó) 


\section{A temető feltárása}

Az egyenes szentélyzáródású Árpád-kori templomtól délre viszonylag kicsi, mintegy $20 \mathrm{~m}^{2}$-es területen temető helyezkedik el. A szobányi területet északról az Árpád-kori templom határolja, nyugatról a templomtól és tornyától dél felé elhelyezkedő kétosztatú épület, délről egy vaskos támfal. Kelet felól nincsen épített lezárása a területnek, hanem fut tovább az Árpád-kori templom, majd a késő középkori templom sekrestyéje mentén. Ezt a területet jelentős terepesés jellemzi a Séd patak felé. A terep formája egyben a kolostor épületegyüttesének dél felé való kiépítését is meghatározta a középkorban.

A feltárt temetóben 16 nyugat-keleti tájolású csontváz került elő - több rétegben és három nagyjából párhuzamos sorban. Az egymást vágó sírok mellett 12 szórvány koponya és csontok jelzik a terület rátemetkezésekkel kialakult bolygatottságát. A sírokat nem jelezte sírfolt. A csontvázakat egységes sárga agyagos, iszapos réteg fogta körül, illetve a sírok egy részét a sárga altalajba ásták. A nagy mennyiségú szög koporsós temetkezésekre utal. A sírok melléklet nélküliek, viseleti elemként is mindössze két kerek övcsat került elő. A támfalakkal övezett, kis alapterületú temetőbe nók temetkeztek, a kolostor apácái és novíciái. Általában ágyékon összekulcsolt kézzel, ritkábban párhuzamosan a test mellé fektetett karokkal helyezték őket végső nyugalomra.

\section{Az északi és nyugati kolostorszárny}

A trapéz alakú kolostorudvar északi felét és az udvart észak és nyugat felől övező épületeket az 1998-2002 közötti kutatási időszakban csak egyegy árokkal tudtuk átvágni. 2010-ben került sor a terület részletesebb kutatására. A kutatás végső célja itt nem az épületszárnyak teljes feltárása volt, hanem az udvart övező falazatok helyreállíthatóságának biztosítása. Végül a középkori udvart övező épületszárnyak csatlakozását tártuk fel viszonylag széles árkokkal, mindkét irányban 12 méter hosszan (4. kép).

A nyugati kolostorszárny feltárása során kibontakozó két helyiség között jelentős szintkülönbséget figyeltünk meg. A délebbi helyiség sárga, öntött mészhabarcs padlója az északi terem rendkívül kemény, jó megtartású terrazzopadlójánál mintegy 20-25 cm-rel mélyebben helyezkedik el. A szintkülönbség határán egy vaskos gerenda omladéka fekszik. Széléhez enyhe homorlattal simul az északra eső helyiség terazzopadlója, jelezve, hogy a gerendával egykorú kiképzésú. A gerenda alapján itt egy faszerkezetes válaszfalat feltételezhetünk. Az észak felé eső helyiségben a terrazzopadló felett nagy mennyiségú vörösre festett vakolattöredéket tartalmazó omladékréteg feküdt, felette az épület falomladéka. A helyiség közvetlen ajtóval nyílt az udvar felé. Az ajtónyílás külső homlokzati síkján jól láthatóak az egykori kókeret fészkei (5. kép 1).

A délebbi helyiségbe dél felól egy viszonylag magas, külső oldalán vakolt, illetve vörösre festett kőküszöbbel rendelkező ajtónyíláson keresztül lehetett bejutni. A küszöb és a padló közötti szintkülönbség mintegy $30 \mathrm{~cm}$. A nyugati szárny észak-déli irányú hosszanti falához képest ez a nyílással áttört válaszfal utólagos, attól falazóhabarcsában is eltér. A válaszfal északi felén vaskos késő középkori - 15-16. századi - szemeskályha omladéka feküdt (9. kép).

A nyugati és az északi kolostorszárny csatlakozásánál, az udvari falsarokban lépcsőalapozást tártunk fel. A lépcsőalap előterében megmunkálás nyomait őrző nagyméretú, nem teljesen kidolgozott vörös kőfaragványokat - köztük malomkövet - építettek a járófelületbe (5. kép 2).

$\mathrm{Az}$ északi épületszárny déli falát az említett lépcsőalap mellett egy kissé rézsús kávájú, a fatok fészkeit és a küszöbfa lenyomatát őrző ajtónyílás tagolja. Az ajtónyílás küszöbszintje mintegy $50 \mathrm{~cm}$-rel magasabban helyezkedik el a fentebb leírt, nagyméretú kövekből képzett járófelületnél (5. kép. 3). Az ajtó előtt egy cölöplyuk jelzi, hogy faszerkezetes lépcső vezetett fel az északi szárny helyiségeibe. Az ajtó mellett egy utólag elfalazott (beforduló vakolatok), szintén

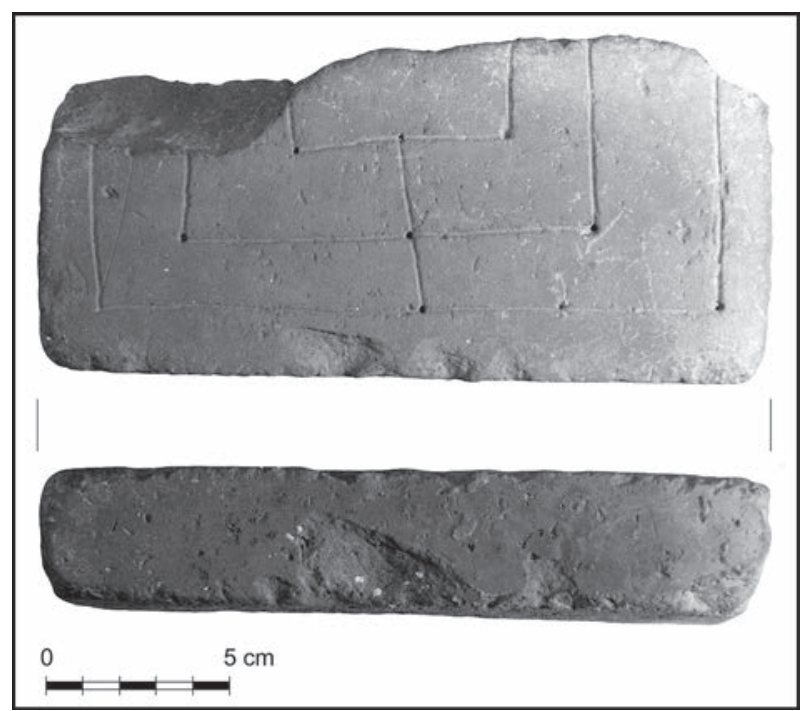

7. kép. Veszprémvölgy. Padlótéglába karcolt malomjáték a kolostor északi szárnyából (Héczey-Markó Ágnes felvétele)

Fig. 7. Veszprémvölgy. Floor tile with an incised Nine Men's Morris game from the northern wing of the convent (photo by Ágnes Héczey-Markó) 


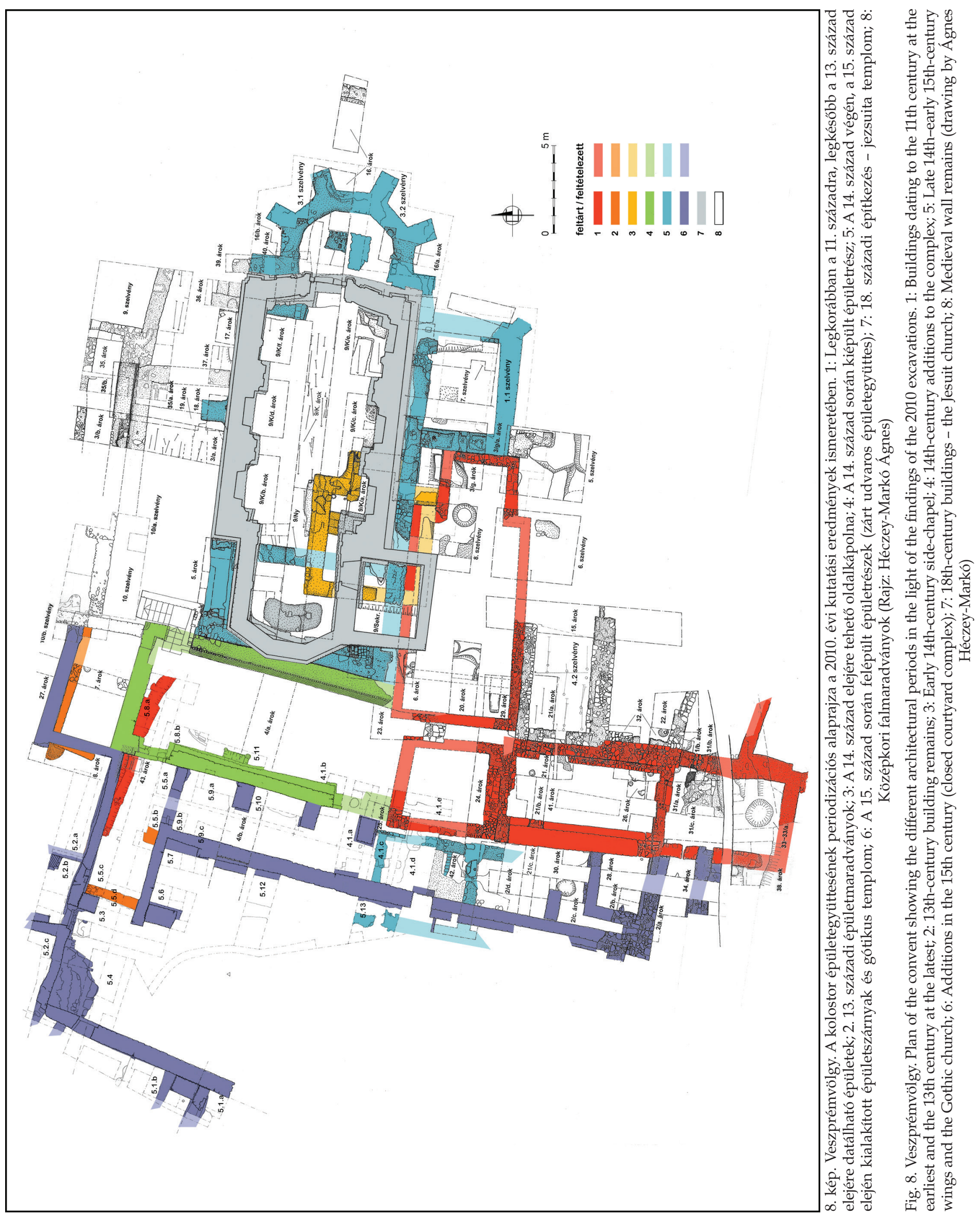


rézsűs kávájú ablaknyílást dokumentáltunk, amelynek in situ fennmaradt az eredeti könyöklőköve. Az ajtó nyugati káváját egy észak felé futó osztófal alkotja, amelyhez utólag hozzáépítettek egy kisebb pillért. A vakolt felületú pillér mögé befut az osztófal vakolata. Az árok középső részén (kelet felé) egy újabb, a helyiségbe kevésbé benyúló, vakolt felületú pillért tártunk fel, amelynek keleti síkjához egy rendkívül sekély alapozású, keskeny, kissé hevenyészett, vegyes falazatú osztófalat emeltek. Ennek nyugati síkja vakolt, keleti síkja eróteljesen lepusztult. Mindezek alapján az északi kolostorszárnyban a kutatott területen szintén két helyiséget különíthetünk el; a nyugatabbra fekvő helyiség vakolata nagy felületeken fennmaradt. A nyugati helyiségben öntött sárga mészhabarcs padló maradványait tártuk fel, alatta pedig kemencealapként szolgáló, égett, barna agyagos, illetve szenes réteggel fedett nagyméretú köveket (sütőfelület), amelyek egy korábbi periódushoz tartoztak. A helyiségekben feltárt másodlagos pillérek egy utólag épített boltozat tartóelemei.

A kolostorudvart északról övező, az északi épületszárny előtt futó folyosószárny a szárnyba vezető falépcsőn megközelíthető ajtó vonalában megszakad. Az ajtó keleti kávájának vonalában a szárny folyosó felóli síkjához egy a folyosóba benyúló pillér csatlakozik. Ezzel szemközt, a folyosót az udvar felé övező falhoz csatlakozva egy további falpillér helyezkedik el. A pillérek és a folyosó hosszanti falai különböző mélységú alapozással rendelkeznek. Az alapokat minden esetben a sárga altalaj fölötti vastag, barna erdőtalajba ásták. A kolostorudvarba nyúló, rendkívül mély alapozással rendelkező pillér folyosó felőli, illetve a nyugati és északi épületszárny sarkában elhelyezkedő lépcső felé eső oldalán markáns járószintet sikerült megfogni, amelyet mészhabarcsból alakítottak ki. A padló teljes kiterjedését ugyan nem tudtuk meghatározni, de elhelyezkedése (az északi és nyugati szárnyba nyíló ajtók, valamint az emeletre felvezetô lépcső találkozáspontja) és minősége alapján feltételezhetjük, hogy valamiféle védőtetővel fedett, megerősített burkolatú közlekedőhöz tartozott.

Az északi folyosót további árkokkal is átvágtuk. Ennek során az északi szárny déli falának előterében egy a sárga altalajba ásott árkot tártunk fel, amelynek sárgásszürke, faszenes betöltéséből késő Árpád-kori, 13. századi kerámia került elő (cserépbogrács-töredékekkel) (6. kép 1, 3). Az árok feltárása során láthatóvá vált egy visszabontott, az északi szárny jelenleg is álló déli fala alatt elhelyezkedő kőfal, amely habarcsában és tájolásában is eltér a felette elhelyezkedő faltól, vonala viszont belevág az említett árokba. Mindezek alapján itt három egymást követő falperiódus határozható meg. A legelsó periódushoz tartozó árok nyugati fele befut az északi szárny déli homlokzati fala alá. Az árok keleti felének vonalát a kolostor keleti épületszárnyának északi végét képező nagyméretú, téglaboltozatos helyiségben is sikerült feltárnunk. Az árkot vágó kőfal vonala kelet felé megszakad a keleti szárny falazatának vonalában, nyugat felé azonban egészen az északi szárny előtt futó folyosó végéig tart, ahol feltártunk egy észak-déli irányú, e fallal egybeépült falmaradványt is. A kutatás során nem volt lehetőség a korai falak teljes kiterjedtségének vizsgálatára.

A keleti szárnyat záró téglaboltozatos helyiségben, a helyiség udvar felóli falának belső oldalán négyzetes objektumot tártunk fel, két belső sarkán cölöplyukakkal. Betöltéséből 14. századi kerámia került elő. Az objektum a földszinti helyiségben álló faszerkezetes építmény lehetett (6. kép 2).

A 2002-ben lezárult kutatás nyomán meghatározhatóvá vált a három templom épületének relatív kronológiája. A kolostorépület első építményének a keleti szárnyat északról lezáró, dongaboltozatos helyiséget/épületet tartottuk. Úgy véltük, hogy az egyenes szentélyzáródású templom és tornya, valamint ez az épület alkothatta a legkorábbi kolostort, feltételezve, hogy faszerkezetes épületek állhattak környezetükben. A 2010. évi kutatások alapján ezt az elképzelést azonban el kell vetnünk, hiszen a dongaboltozatos helyiség falai ráfednek egy 13. századi betöltési réteget tartalmazó árokra, így az épületrészt legkorábban a 13. század végén, a 14. század elején építhették.

2002-ben az Árpád-kori templomtól délre elhelyezkedő, egytraktusos épületszárnyat tekintettük a második építési fázisnak. Áttekintve az épületek elhelyezkedését, szintviszonyait és egymáshoz való viszonyát, a 2010-es kutatás után ezt az épületrészt kell korábbinak tartanunk. A templom, a közel hajó szélességú torony és a templom-torony hossztengelyére merőlegesen elhelyezkedő, dél felé futó kétosztatú épület egységes építészeti megoldást mutat. Ezt a periódust - figyelembe véve az egyenes szentélyzáródású templom keltezésének fentebb ismertetett problémáit - általánosító kijelentéssel Árpád-korinak kell tartanunk. A legkorábbi lehetséges kialakítást a 11. századra, a legkésőbbit a 13. századra datálhatjuk. 


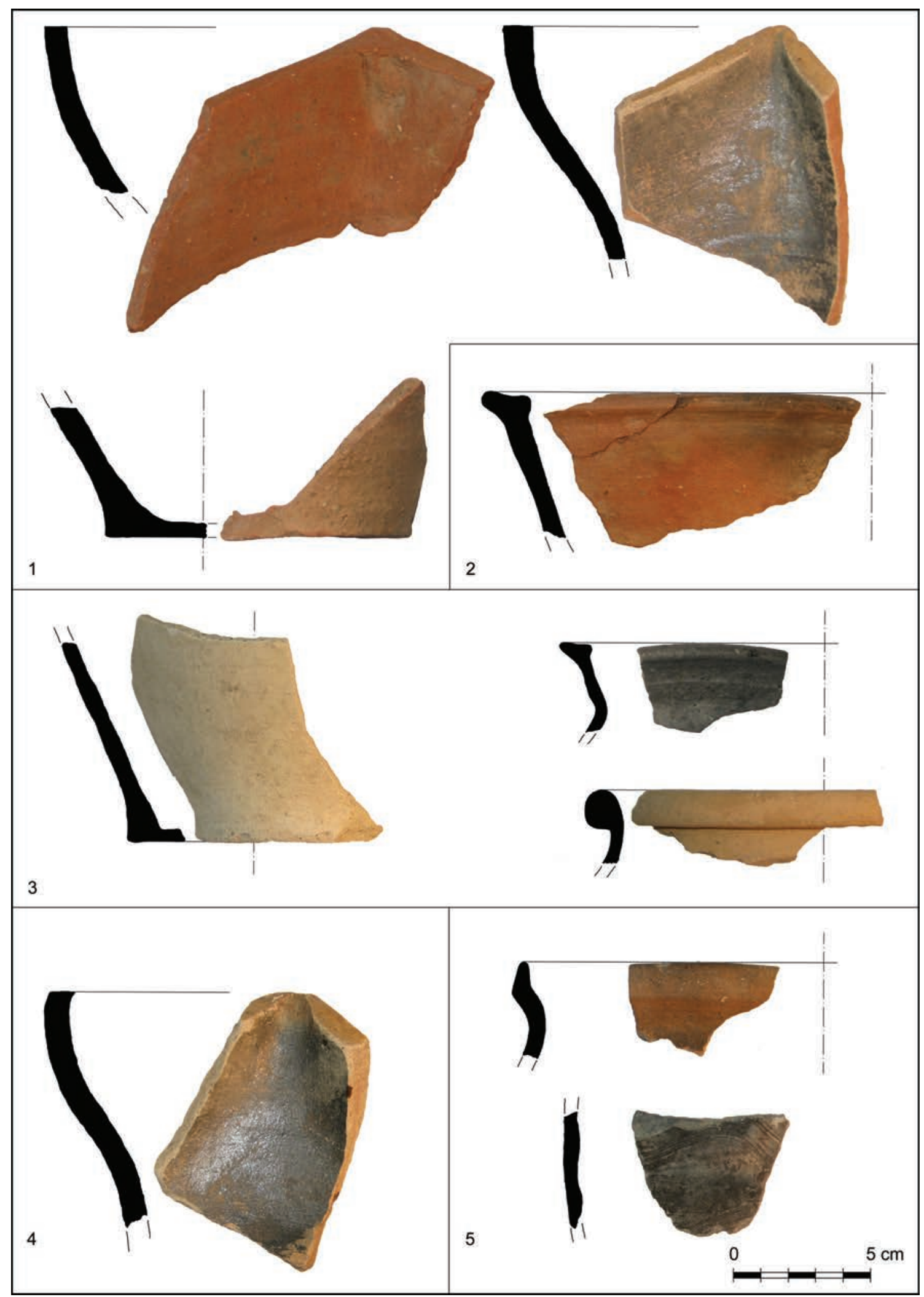

9. kép. Veszprémvölgy, a feltárás leletei. 1: 5.1. árok, 15-16. századi kályhaszem; 2: 5.1. árok, 15. századi kerámia; 3: 5.1. árok, 14. századi kerámia a mészhabarcs padló alól; 4: 5.1. árok, 15-16. századi kályhaszem; 5: 5.2. árok, 11. századi kerámia a sárga agyagos járószint alatti feltöltésből (Héczey-Markó Ágnes felvételei; rajz: Lovas Franciska)

Fig. 9. Veszprémvölgy, finds from the excavation. 1: Trench 5.1, 15th-16th-century stove tile; 2: Trench 5.1, 15th-century pottery; 3: Trench 5.1, 14th-century pottery from underneath the lime mortar floor; 4: Trench 5.1, 15th-16th-century stove tile; 5: Trench 5.2, 11th-century pottery from the fill underneath yellow clayey occupation level (photos by Ágnes Héczey-Markó, drawing by Franciska Lovas) 


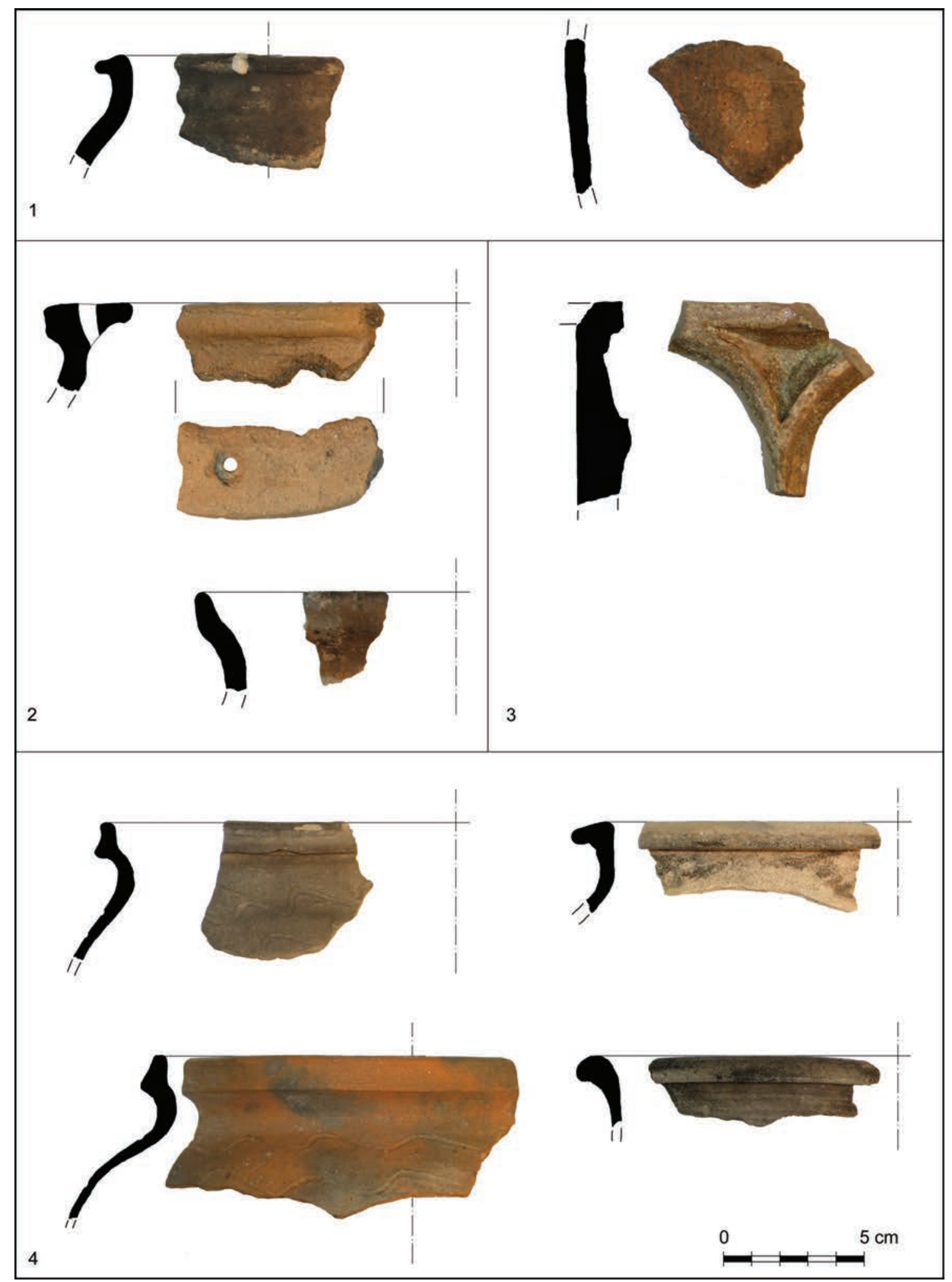

10. kép. Veszprémvölgy, a feltárás leletei. 1: 5.5. árok, 11. (12.) századi kerámia az északi épületszárny folyosó felőli kőfala által vágott árok betöltéséből; 2: 5.8. árok, 12. századi kerámia az északi épületszárny folyosó felőli kőfala által vágott árok betöltéséből; 3: 5.9. árok, 15. századi kályhacsempe; 4: 5.11. árok, 14. századi kerámia a dongaboltozatos helyiség belsó terében egykor állt, cölöpszerkezetú építmény betöltéséből (Héczey-Markó Ágnes felvételei; rajz: Lovas Franciska)

Fig. 10. Veszprémvölgy, finds from the excavation. 1: Trench 5.5, 11th (12th)-century pottery from the fill of the ditch cut by the stone wall by the corridor of the northern wing; 2 : Trench $5.8,12$ th-century pottery from the fill of the ditch cut by stone wall by the corridor of the northern wing; 3 : Trench 5.9, 15th-century stove tile; 4 : Trench $5.11,14$ th-century pottery from the fill of the post-framed structure inside the barrel-vaulted room (photos by Ágnes Héczey-Markó, drawing by Franciska Lovas) 


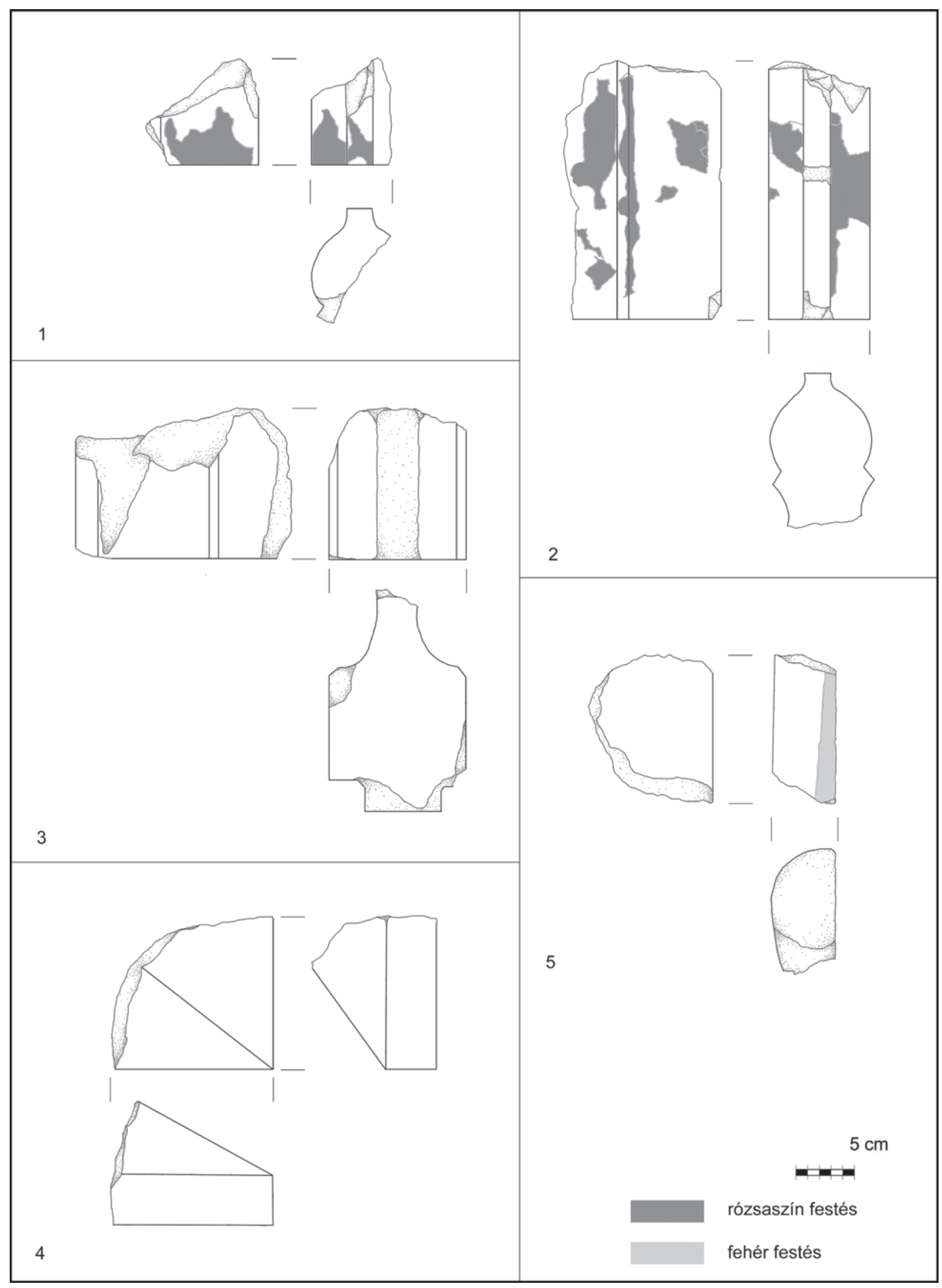


11. kép. Veszprémvölgy, kőfaragványok. 1-2: Zsigmond-kori gótikus bordatöredék a gótikus szentélyből; 3: Boltozati bordatöredék a dongaboltozatos helyiség betöltéséből; 4: Középkori gyámkő vagy lábazati faragott kőelem a nyugati épületszárnyból; 5: Román tagozattöredék az északi épületszárnyból (Felmérés és rajz: Héczey-Markó Ágnes)

Fig. 11. Veszprémvölgy, stone carvings. 1-2: Gothic rib fragments from the Gothic sanctuary, Sigismund period; 3: Vault rib fragment from the fill of the barrel-vaulted room; 4: Medieval corbel or carved base element from the western wing; 5: Romanesque element fragment from the northern wing (survey and drawing by Ágnes Héczey-Markó)

A kolostor épületeinek elhelyezkedését már ennek az L alakú épületegyüttesnek a kialakításakor nagymértékben befolyásolta, hogy az Árpád-kori templomtól délkeletre jelentős terepesés tapasztalható: itt a patakvölgy és feltehetően az egykori meder is közelebb helyezkedett el az épülethez.

A kolostor épületétől északra fekvő területen a késóbbi északi udvari szárny alatt - több olyan objektum, épületmaradvány is előkerült, amelyek fokozatos kiépülésre utalnak. Ilyen a már részletezett két, 13. századi betöltési réteggel rendelkező árok és cölöpépítmény, valamint azok a korai falak, amelyek vágják a betöltött árkokat, és egy épület közelebbről meg nem határozható részleteihez tartoznak. Ezen a területrészen tehát olyan épületek, melléképületek épültek fel a 13. század tól, amelyek később meghatározóak lettek a kolostor alaprajzi rendszerében. Az említett korai falak alkotta épület hosszvonala tompaszöget zár az egyenes szentélyzáródású korai templom hossztengelyével.

A 14. század elején kriptával rendelkező, gazdagon kifestett oldalkápolna épült a templom északi falához. A kápolnának csupán az északi harmada maradt meg. Maradványait jelentősen roncsolta, hogy mind a későbbi gótikus, mind a barokk templom déli fala ráépült. Felépítésük és alapozásuk során a kápolna déli felét gyakorlatilag elpusztították.

A 14. század második felében, a század végén nagyobb építkezések alakították tovább a kolostor építészeti képét. Ekkor épült a már többször említett, dongaboltozatos helyiség a templom tornyától észak felé. A helyiség hossztengelye a tóle északra lévő korábbi melléképülethez illeszkedik, egységesebb épületegyüttest kialakítva. Ezt követően egy nagyobb templom felépítésének előkészületeként elbontották a kriptás oldalkápolnát, majd röviddel ezután a templomtól délre elhelyezkedő keleti kolostorszárny mellé újabb traktust építettek. (Erről a traktusról feltételezzük, hogy az írott forrásból ismert Konch mester építette.) A 14. század végén, a 15. század elején a korábbi Árpád-kori templomépülettől északra épült fel a gótikus templom, amely részben felülrétegezte az akkor ott húzódó temetőt. E templom oldalkápolnájaként szolgálhatott tovább az egyenes szentélyzáródású korai templom.

Végül a 15. század során elbontották a Konchféle épületet. A teljes keleti szárny előtt folyosót alakítottak ki úgy, hogy az az északi szárny elé is befordult. Ezzel egy időben - vagy ezt követóen - épült fel a trapéz alakú udvart övezó épületegyüttes, és nyerte el a kolostor legnagyobb ismert kiterjedését (8. kép).

A 2010. évi kutatást a romterület és a területen álló jezsuita templom helyreállítása követte. ${ }^{21}$ A helyreállítás tervezése során az eredeti falak falkoronaszintjeinek megemelésével, lezárásával, az egykori ajtónyílások helyreállításával az épületromok karakterének megörzése volt a cél. A keleti szárny végén elhelyezkedő, dongaboltozatos helyiség fölé részben visszakerült a boltozat. Ott, ahol a feltárás véget ért, a terep felső síkjának rendezésével a romfalak mintegy befutnak a füvesített terepbe. A romterületen modern lépcsők segítik a közlekedést és egyben az átláthatóságot.

A jezsuita templom belső terében járható üvegfelület alatt bemutatásra került a 14. századi oldalkápolna és kriptájának maradványa.

A területet egykor záró kőkerítés elbontásával ismét létrejött a romok és a Séd völgyének kapcsolata. A patak felől az enyhén emelkedő völgyoldal parkjából emelkedik ki fokozatosan a veszprémvölgyi apácakolostor romja.

21 A helyreállítást Máté Zsuzsanna és Bíró Zsófia építészmérnökök, valamint Remeczki Rita táj- és kertépítész mérnök tervezték. 


\section{IRODALOM}

BALOg Albin

1946 A veszprémvölgyi görög monostor alapítása. A legrégibb magyarországi oklevél. Regnum 6 (1944-46) 21-30.

BOGDÁN ISTVÁN

1978 Magyarországi hossz- és földmértékek a XVI. század végéig. Budapest.

CD

Georgius Fejér: Codex diplomaticus Hungariae. Buda, 1829-1844.

DARKÓ JENŐ

1917 A veszprémi apáczamonostor alapító-levelének 1109-i másolatáról. Egyetemes Philológiai Közlöny 41, 257-272, 336-351.

ÉRSZEGI GÉZA

1988 Szent István görög nyelvú okleveléről. Levéltári Szemle (Budapest) 38/3, 3-13.

2000 A veszprémvölgyi alapítólevél. In: Kredics L. (szerk.): Válaszúton. Pogányság-kereszténység, keletnyugat. Konferencia. Veszprém, 2000. május 8-10. Veszprém, 159-175.

FEJÉRPATAKy LÁSZLÓ

1892 Kálmán király oklevelei. Értekezések a történeti tudományok köréből 15. Budapest, 195-282.

FÜLÖP ANDRÁs-KOPPÁNY ANDRÁs

2002 A veszprémvölgyi apácakolostor régészeti kutatása (1998-2002). Múemlékvédelmi Szemle 12/1, 5-40.

2004 A crosier from the territory of the Veszprémvölgy convent. Acta Archaeologica Academiae Scientiarum

GuTHEIL JENŐ Hungaricae 55, 115-135.

1977 Az Árpád-kori Veszprém. Veszprém.

GYOMLAY GYULA

1901 Szent István veszprémvölgyi donatiójának görög szövegéról. Értekezések a nyelv- és széptudományi osztály köréból 17. Budapest, 391-434.

GYÖRFFY GYÖRGY

1977 István király és múve. Budapest.

1992 Diplomata Hungariae Antiquissima I. 1001-1131. Budapest.

HERVAY FERENC

1984 Repertorium Historicum Ordinis Cisterciensis in Hungaria. Roma.

HÓMAN BÁLINT

1911 A veszprémvölgyi 1109. évi oklevél hitelessége. Turul (Budapest) 29, 123-134, 167-174.

1917 Szent István görög oklevele. Századok (Budapest) 51, 99-136, 225-242.

HORVÁt ISTVÁN

1834 Boldog Asszony Veszprém Völgyi Apátza Monostorának alkató Görög Oklevele Szent István Magyar Királytól Kálmán Magyar Királynak 1109-dik évi hiteles Másolatából, két Réz Táblával. Tudományos Gyújtemény (Pest) 1, 84-106.

KOMJÁtHY MiKLÓs

1971 A veszprémvölgyi alapítólevél kibocsátójáról. Levéltári Közlemények (Budapest) 42/1, 33-49

LÁSZLÓ GYULA

1963 A magyar pénzverés kezdeteiről. Századok (Budapest) 97, 382-397.

MMúv

1987 Marosi E. (szerk.): Magyarországi múvészet 1300-1470 körül I. Budapest.

MORAVCSIK GYULA

1938 Görög nyelvú monostorok Szent István korában. In: Serédi J. (szerk.): Emlékkönyv Szent István király

halálának kilencszázadik évfordulóján I. Budapest, 389-422.

MRT 2.

Az Árpád-kori magyar történet bizánci forrásai. Budapest.

1969 Éri István-Kelemen Márta-Németh Péter-Torma István: Magyarország régészeti topográfiája 2. Veszprém megye régészeti topográfiája. Veszprémi járás. Szerk.: Torma I. Budapest.

SZENTPÉTERY IMRE

1923 Az Árpád-házi királyok okleveleinek kritikai jegyzéke I. Budapest.

1930 Magyar oklevéltan. Budapest.

1938 Szent István király oklevelei. In: Serédi J. (szerk.): Emlékkönyv Szent István király halálának kilenc-

$\mathrm{ZsO}$ I. századik évfordulóján II. Budapest, 135-202.

1951 Zsigmond-kori oklevéltár I. 1387-1399. Összeállította: Mályusz Elemér. Budapest. 


\section{NEW RESULTS IN THE ARCHAEOLOGICAL INVESTIGATION OF THE VESZPRÉMVÖLGY CONVENT}

\section{ÁGNES HÉCZEY-MARKÓ-ANDRÁS KoPPÁNY}

The archaeological investigation of the Veszprémvölgy convent in summer 2010 immediately preceded the conservation of the ruins area. The excavation primarily focused the areas affected by the planned conservation work, where we re-excavated the areas explored earlier, between 1998 and 2002, and we also had the opportunity to uncover buildings that had not been investigated earlier. The findings of the excavation enabled the reconstruction of the architectural history of the convent that was organised around a trapezoidal courtyard, namely of the process whereby the early convent made up of a church and a building dating to the 11th century at the earliest gradually attained its final form after several rebuildings. While the post-11th-century building work could be securely dated, it remains an open question whether the buildings regarded as being the earliest can be dated to the reign of István I (997-1038). The greater part of the convent's late medieval wings remains unexcavated and further research in the complex's broader area is necessary in order to gain a full picture of the architectural history of the Veszprémvölgy convent. 